\title{
Surface Modification of Reconstituted Hemoglobins Containing SOD-Active Metalloporphyrins
}

\author{
Makoto Yuasa $^{1 *, 2}$, Kenichi Oyaizu ${ }^{2}$, Aritomo Yamaguchi ${ }^{1}$, Takamitsu Hayashi ${ }^{1}$ \\ and Uichi Midorikawa ${ }^{\mathbf{1}}$ \\ ${ }^{1}$ Department of Pure and Applied Chemistry, Faculty of Science and Technology, Tokyo University of Science \\ (Noda 278-8510, JAPAN) \\ ${ }^{2}$ Institute of Colloid and Interface Science, Tokyo University of Science \\ (Tokyo 162-8601, JAPAN)
}

Edited by T. Itoh, Kitasato Univ., and accepted October 6, 2004 (received for review August 10, 2004)

\begin{abstract}
Reconstituted hemoglobins modified with polyethylene glycol (PEG) containing iron(III) and manganese(III) complexes of meso-tetra( $N$-methylpridinium- $x$ yl)porphyrin ([MTxMePyP]-Hb-PEG, $\mathrm{M}=\mathrm{Fe}$ and $\mathrm{Mn}, x=2$ and 4) were found to serve as excellent superoxide dismutase (SOD) mimics under physiological conditions. $\mathrm{IC}_{50}$ was $2.3 \mu \mathrm{M}$ and the pseudo-first order rate constant was $2.2 \times 10^{6} \mathrm{M}^{-1} \mathrm{~s}^{-1}$ for reaction of MnT2MePyP-HbPEG with a superoxide anion radical as detemined by conventional cytochrome $c$ assay and stopped flow analysis, respectively. Stability toward $\mathrm{H}_{2} \mathrm{O}_{2}$ by surface modification of reconstituted hemoglobins with PEG chains helped prevent aggregation with other proteins such as albumin.

Key words: superoxide anion radical, superoxide dismutase, SOD mimic, reconstituted hemoglobin, cationic metalloporphyrin
\end{abstract}

\section{1 緒言}

生体に取り込まれた酸素 $\left(\mathrm{O}_{2}\right)$ は，紫外線や放射線 との相互作用, 酵素反応などの影響を受けると, スー パーオキシドアニオンラジカル $\left(\mathrm{O}_{2}{ }^{-} \cdot\right)$ に変化する。 $\mathrm{O}_{2}{ }^{-} \cdot$ はスーパーオキシドジスムターゼ (SOD) により 過酸化水素 $\left(\mathrm{H}_{2} \mathrm{O}_{2}\right)$ と $\mathrm{O}_{2}$ へと不均化され, さらに $\mathrm{H}_{2} \mathrm{O}_{2}$ は, カタラーゼ (Cat), グルタチオンペルオキシ ダーゼ（GSH）などの酵素により，水 $\left(\mathrm{H}_{2} \mathrm{O}\right)$ にまで 代謝される。しかし，炎症や疾患のときは，これらの 活性酸素の生成と消去のバランスが崩れ, 酸化ストレ ス状態となり, $\mathrm{O}_{2}{ }^{-} \cdot$ が過剩に発生することが知られて いる。この結果, 特に有害な（反応性が高い）活性酸 素であるヒドロキシラジカル $(\mathrm{OH} \cdot)$ やペルオキシナ イトライトイオン $\left(\mathrm{ONOO}^{-}\right)$が発生し, DNA, タンパ
\end{abstract}

ク質, 糖, 脂質, 血管などを攻撃し, 合併症や細胞死 を引き起こすと考えられている $(1,2)$ 。このため, 生 体内の活性酸素種の消去・代謝に関する研究が行われ， $\mathrm{O}_{2}{ }^{-}$.の消去・代謝反応 [(1) 式] を促進する人工 SOD モデル化合物が提案された（2-14）。人工 SOD モデルの 研究によって体内の $\mathrm{O}_{2}{ }^{-}$. を消去する薬㓮が開発されれ ば，活性酸素から細胞を守ることが可能になる。近年， 生体内に存在するへムタンパク質の活性部位（へム） である金属ポルフィリンに注目した研究が多く報告さ れている（3-5,10,13）。著者らは，生体適合性や安定性 を考慮した新規 SOD モデル化合物として，へモグロビ ンのアポタンパク質（4 個のグロビン鎖サブユニットの 集合体）を担体とし，その活性部位として SOD 活性を 有する金属ポルフィリン誘導体を導入した再構成へモ グロビン（Fig. 1, 2～5）について調べた（14）。本報

*Correspondence to: Makoto YUASA, Department of Pure and Applied Chemistry, Faculty of Science and Technology, Tokyo University of Science, Noda 278-8510, JAPAN

E-mail: yuasa@rs.noda.tus.ac.jp 
では, 安定性の向上を目指してポリエチレングリコー ル（PEG）を修飾した再構成へモグロビン（Fig. 1, 6 ～9）を合成し，それらのSOD 活性などについて調べ た。

$$
2 \mathrm{O}_{2}^{-} \cdot+2 \mathrm{H}^{+} \rightarrow \mathrm{O}_{2}+\mathrm{H}_{2} \mathrm{O}_{2}
$$

\section{2 実験}

$2 \cdot 1$ 試 料

活性部位に相当する各種金属ポルフィリン錯体であ る鉄 $\{5,10,15,20$-テトラキス（N-メチルピリジニウム-2イル）ポルフィリン\} (FeT2MePyP)，鉄 $\{5,10,15,20$-テ トラキス（N-メチルピリジニゥム-4-イル）ポルフィリ ン $\}(\mathrm{FeT} 4 \mathrm{MePyP})$ ，マンガン $\{5,10,15,20$-テトラキス (N-メチルピリジニウム-2-イル) ポルフィリン\} (MnT2MePyP) 执よびマンガン $\{5,10,15,20$-テトラキ ス（N-メチルピリジニウム-4-イル）ポルフィリン\}
（MnT4MePyP）は，既報（15-19）により合成した。な お，これらの化合物の構造確認は ${ }^{1} \mathrm{H}-\mathrm{NMR}$ (JEOL JNMAL300), FAB-Mass(JEOL JMS-SX102A), UV-vis. (SHIMADZU UV-2100）スペクトル等により行った。

ヘモグロビン（1）は成人ヒトへモグロビン[へモグ ロビン $\mathrm{A}$, 和光純薬]を使用した。他の試薬は市販特級 を用いた。

\section{$2 \cdot 2$ 再構成へモグロビンの合成}

Fig. 1 に示した 8 種類の再構成へモグロビン（2 9）は既に報告された方法（14，19-24）により合成した (Fig. 2)。

$2 \cdot 2 \cdot 1 \quad \mathbf{2} \sim \mathbf{5}$ の合成

再構成へモグロビン $(\mathbf{2} \sim \mathbf{5})$ のそれぞれの収率は次 の通りであった。2：収率 $83 \%$, UV-vis. $\left(\lambda_{\max }, \mathrm{nm}\right.$, $\left.\mathrm{H}_{2} \mathrm{O}\right) ： 411,587$ 。3 : 収率 $83 \%$, UV-vis. $\left(\lambda_{\max }, \mathrm{nm}\right.$, $\left.\mathrm{H}_{2} \mathrm{O}\right) ： 424,598$ 。4：収率 $83 \%$, UV-vis. $\left(\lambda_{\max }, \mathrm{nm}\right.$,

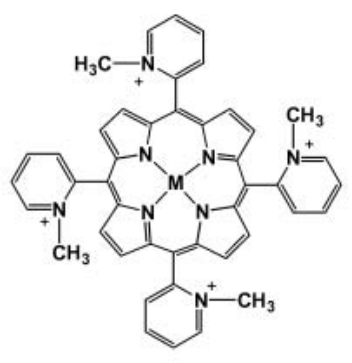

MT2MePyP

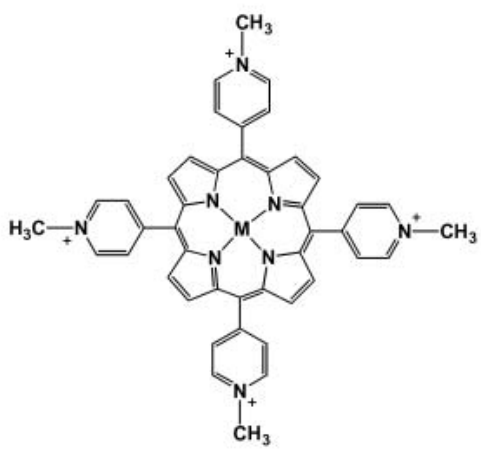

MT4MePyP

$\mathrm{M}=\mathrm{Fe}$ or $\mathrm{Mn}$

\begin{tabular}{c|c}
\hline Abbreviation & Compound \\
\hline$\underline{\mathbf{1}}$ & $\mathrm{Hb}$ \\
\hline$\underline{\mathbf{2}}$ & FeT2MePyP-Hb \\
\hline$\underline{\mathbf{3}}$ & FeT4MePyP-Hb \\
\hline$\underline{\mathbf{4}}$ & MnT2MePyP-Hb \\
\hline$\underline{\mathbf{5}}$ & MnT4MePyP-Hb \\
\hline$\underline{\mathbf{6}}$ & FeT2MePyP-Hb-PEG \\
\hline$\underline{\mathbf{7}}$ & FeT4MePyP-Hb-PEG \\
\hline$\underline{\mathbf{8}}$ & MnT2MePyP-Hb-PEG \\
\hline$\underline{\mathbf{9}}$ & MnT4MePyP-Hb-PEG \\
\hline
\end{tabular}

Fig. 1 Hemoglobin (1), Various Reconstituted Hemoglobins (2 to 7 ) and Reconstituted Hemoglobins Modified with Polyethylene Glycol (PEG) (6 to 9). 


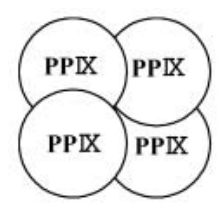

$\mathrm{Hb}$

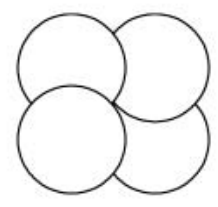

apo-Hb

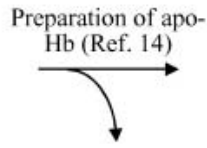

PPIX

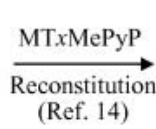

(Ref. 14)

1

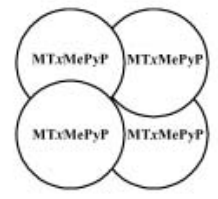

MTxMePyP-Hb

$\underline{\mathbf{2}} \sim \underline{\mathbf{5}}$
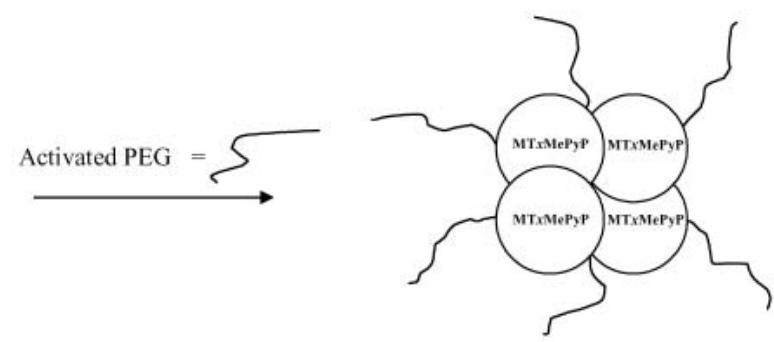

MT $x$ MePyP-Hb-PEG

$$
\underline{6} \sim \underline{9}
$$

Fig. 2 Syntheses of Various Reconstituted Hemoglobins (2 to 5) (Ref. 14) and Various Reconstituted Hemoglobins Modified with PEG ( 6 to 9 ). Compounds $\mathbf{1}, \mathbf{2}$ to 5 and $\mathbf{6}$ to $\mathbf{9}$ are hemoglobin, reconstituted hemoglobins and reconstituted hemoglobins modified with PEG, respectively, as shown in Fig. 1. MT $x \mathrm{MePyP}=\mathrm{FeT} 2 \mathrm{MePyP}$, FeT4MePyP, MnT2MePyP or MnT4MePyP.

$\left.\mathrm{H}_{2} \mathrm{O}\right) ： 455,560$ 。 5 ：収率 $83 \%, \mathrm{UV}$-vis. $\left(\lambda_{\max }, \mathrm{nm}\right.$, $\left.\mathrm{H}_{2} \mathrm{O}\right): 454,555$ 。

$2 \cdot 2 \cdot 2$ 活性化ポリエチレングリコール（ActivatedPEG）の合成

Activated-PEG の合成は既報（22-24）の方法を工夫し て行った。数平均分子量 7500 の PEG (100 g) をジメ チルホルムアミド (DMF) (100 ml) に溶解させ, 無水

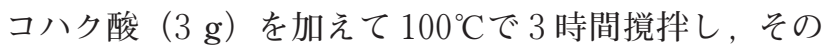
後，室温になるまで放置し，ガラスフィルターを用い て吸引ろ過した。さらに, 未反応の無水コハク酸を除 去するため，ジエチルエーテル $(500 \mathrm{ml})$ を用いて洗 浄した。この後, 室温で 6 時間減圧乾燥することによ り，末端にカルボキシル基を有する PEG-COOH が得ら れた (収率 90\%)。得られた PGE-COOH (98.5 g) を DMF $(100 \mathrm{ml})$ に溶解させ， $N$-ヒドロキシコハク酸 $(2.95 \mathrm{~g})$ とジシクロヘキシルカルボジイミド $(5.29 \mathrm{~g})$ を加え $30^{\circ} \mathrm{C} て ゙ 24$ 時間擋拌し，ガラスフィルターを用い て吸引ろ過した。さらに，未反応の $N$-ヒドロキシコハ ク酸イミドとジシクロヘキシルカルボジイミドを除去 するため, ジエチルエーテル $(500 \mathrm{ml})$ を用いて洗浄 した。この後, 室温で 6 時間減圧乾燥することにより, 末端にコハク酸イミドエステルを持つ Activated-PEG が 得られた（収率 86\%)。化合物の構造確認は ${ }^{1} \mathrm{H}-\mathrm{NMR}$
(JEOL JNM-AL300), IR（SHIMADZU FTIR-8200PC) スペクトルなどにより行った。

\section{$2 \cdot 2 \cdot 3 \quad 6 \sim 9$ の合成}

PEG 修飾再構成へモグロビン（6～9） は下記のよ うに合成した。

\section{(1) 6 の合成}

2 を水浴中で 1 時間アルゴン脱気し，ピリドキサー ル-5-リン酸 1 水和物（PLP）（2.46 mg） と水素化ホウ素 ナトリウム $(1.7 \mathrm{mg})$ を加え, 30 分間摚找し, 前項で 得られた Activated-PEG (0.4 g) を加え, 1 時間擋拌し た。反応後, 水浴中で 2 時間放置し, 沈殿した未反応 のPEG をろ過した。未反応の PLP と水素化ホウ素ナト リウムを除去するため, 透析（VSC, SCT UC8-32-25/pH 7.0/0.3 M/12 時間）を行った。さらに GPC（東ソー, トヨパール HW-55F) を用いて, 未反応の PEG を除去 することにより，目的物質である $\mathbf{6}$ が得られた（収率 $75 \%)$ 。

\section{（2） $\mathbf{7 , 8}$ および $\mathbf{9}$ の合成}

3, 4 打よび 5 を用いて 2 と同様の操作を行うことに より，それぞれ 7 (収率 75\%)，8（収率 75\%）打よび 9 (収率 75\%) が得られた。 


\section{$2 \cdot 3$ 測定}

$2 \cdot 3 \cdot 1$ ゲルろ過クロマトグラフィー (GPC) による 分子量の測定

各種 PEG 修飾再構成へモグロビン $(6$ ～9）の分子 量を GPCによって測定した。測定は高速液体クロマト グラフ (SHIMADZU, LC-10AT), UV 検出器 (SHIMADZU, SPD10A), 分離カラム (Shodex, OHpak SB803HQ）を用いて行った。GPC の検量線は, 分子量既 知の PEG とへモグロビンを用いて作成した。溶離液に は $\mathrm{pH} 7.0$ の $0.1 \mathrm{M}$ リン酸緩衝溶液を使用し, $30^{\circ} \mathrm{C}$ で流 速 $0.6 \mathrm{ml} / \mathrm{min}$ にて測定した。また, 参照物質として, ヘモグロビン（1）の GPC 測定も行った。

\section{$2 \cdot 3 \cdot 2$ SOD 活性測定}

$2 \cdot 3 \cdot 2 \cdot 1$ シトクローム $c$ 法による SOD 活性測定

各種 PEG 修飾再構成へモグロビン $(\mathbf{6} \sim 9)$ の SOD 活性を, シトクローム $c$ 法 $(14,25,26)$ により測定し た。また，参照物質として，へモグロビン $(\mathbf{1})$, 各種 再構成へモグロビン $(\mathbf{2} \sim \mathbf{5})$ 扎よび低分子系 SOD モ デル化合物であるカチオン性金属ポルフィリン ( FeT2MePyP, FeT4MePyP, MnT2MePyP および MnT4MePyP）についても同様にSOD 活性を測定し た。

$2 \cdot 3 \cdot 2 \cdot 2$ ストップトフロー法による SOD 活性測定

PEG 修飾再構成へモグロビン（8）の SOD 活性を， ストップトフロー法（27）により測定した。混合装置 には UNISOKU 製自動コック付ミキシング装置を用い た。分光測定装置には UNISOKU 製ラピッドスキャン 分光測定装置を用いた。ストップトフロー法により，2 種類以上の溶液を迅速に混合し，溶液の吸光度を経時 的に測定した。金属ポルフィリン濃度で $0 \sim 24 \mu \mathrm{M}$ の 各種 PEG 修飾再構成へモグロビン溶液を $\mathrm{pH} 7.8$ の 300 $\mathrm{mM}$ リン酸緩衝溶液で希釈し，4 水準以上調製した（A 溶液)。超酸化カリウム $(1 \mathrm{~g})$ をジメチルスルホキシド （DMSO）に分散させて飽和溶液を調整し，さらに 30 分間摚找した (B 溶液)。一方のシリンダーに A 溶液 を, 他方のシリンダーにB 溶液を入れ, セルの温度を $36^{\circ} \mathrm{C}$ に設定した。体積比 A : B = 20: 1 にて混合した 後， $270 \mathrm{~nm}$ における吸光度の経時変化を測定した。ま た，参照物質として，再構成へモグロビン（2 および 4), 低分子系 SOD モデル化合物であるカチオン性金属 ポルフィリン（MnT2MePyP および MnT4MePyP）に ついても同様にSOD 活性を測定した。

\section{$2 \cdot 3 \cdot 3 \quad \mathrm{H}_{2} \mathrm{O}_{2}$ に対する安定性評価}

既報の方法 (14, 28-30) にて 8 の $\mathrm{H}_{2} \mathrm{O}_{2}$ に対する安定 性を評価した。金属ポルフィリン濃度で $1 \mu \mathrm{M}$ の各種 PEG 修飾再構成へモグロビン溶液（試料溶液）に，1 $\mathrm{mM}$ の $\mathrm{H}_{2} \mathrm{O}_{2}$ 水溶液（金属ポルフィリンに対して 1000 倍モル量）を添加した後に, 金属ポルフィリン錯体 $\left(\lambda_{\text {max }}=450 \mathrm{~nm}\right.$ 付近）における吸光度の経時変化を測 定した。また，参照物質として，へモグロビン（1) $\left(\lambda_{\text {max }}=400 \mathrm{~nm}\right.$ 付近 $)$ ，再構成へモグロビン $(\mathbf{4})$ 打よ び低分子系 SOD モデル化合物であるカチオン性金属ポ ルフィリン $(\mathrm{MnT} 2 \mathrm{MePyP})$ についても同様に $\mathrm{H}_{2} \mathrm{O}_{2}$ に 対する安定性を評価した。

\section{$2 \cdot 3 \cdot 4$ アルブミンとの凝集能の測定}

$\mathrm{MnT} 2 \mathrm{MePyP}$ 系の再構成へモグロビンとアルブミン (和光純薬) との凝集能を測定した。0.096 g/mlのアル ブミン溶液 $1 \mathrm{ml}$ とシトクローム $c$ 法に打ける $\mathrm{IC}_{50}$ 濃度 の 2 倍に相当する $8(1 \mathrm{ml})$ をそれぞれ $36^{\circ} \mathrm{C} て ゙ ~ 10$ 分間 放置した後に混合し，金属ポルフィリン錯体 $\left(\lambda_{\max }=\right.$ $450 \mathrm{~nm}$ 付近）に打ける吸光度の経時変化を測定した。 また，参照物質として，へモグロビン（1） $\left(\lambda_{\max }=400\right.$ $\mathrm{nm}$ 付近）および低分子系 SOD モデル化合物であるカ チオン性金属ポルフィリン $(\mathrm{MnT} 2 \mathrm{MePyP})$ についても 同様にアルブミンとの凝集能を測定した。

\section{3 結果および考察}

\section{$3 \cdot 1$ GPC 測定}

GPC により算出される数平均分子量 $\left(M_{\mathrm{n}}\right)$, 多分散 度 $\left(M_{\mathrm{w}} / M_{\mathrm{n}}\right)$ およよ゙ (2) 式から修飾された PEGの本 数を求めた（Table 1)。また，代表例として, PEG 修 飾再構成へモグロビン（8）とへモグロビン（1）の流 出クロマトグラムを Fig. 3 に示す。

人工血液の分野では，酸素運搬体として PEG 修飾へ モグロビンの代用が研究されて打り，ラット血液の 60\%を PEG 修飾へモグロビン溶液に置き換えたもの は，その半減期が約 12.8 時間であることが報告されて いる（ストローマフリーへモグロビンでは約 2.2 時間） (22)。また，へモグロビンは血中に打いて，サブユ ニット間での解離 (分子量が 64500 から 32250 に減少) が進行し，腎臓の糸球体を通過して排出されてしまう が，一般に分子量 50000 以上であればこの排出が抑止

Table 1 Molecular Weights of Hemoglobin (1) and Various Reconstituted Hemoglobins Modified with PEG $(\mathbf{6}$ to 9$)$.

\begin{tabular}{c|c|c|c}
\hline Abbreviation & $10^{5} \times M_{\mathrm{n}}$ & $M_{\mathrm{w}} / M_{\mathrm{n}}$ & Number of PEG \\
\hline $\mathbf{1}$ & 0.645 & 1.05 & 0 \\
\hline $\mathbf{6}$ & 1.27 & 1.26 & 7.9 \\
\hline $\mathbf{7}$ & 1.33 & 1.28 & 8.5 \\
\hline $\mathbf{8}$ & 1.29 & 1.28 & 8.1 \\
\hline $\mathbf{9}$ & 1.36 & 1.13 & 9.0 \\
\hline
\end{tabular}




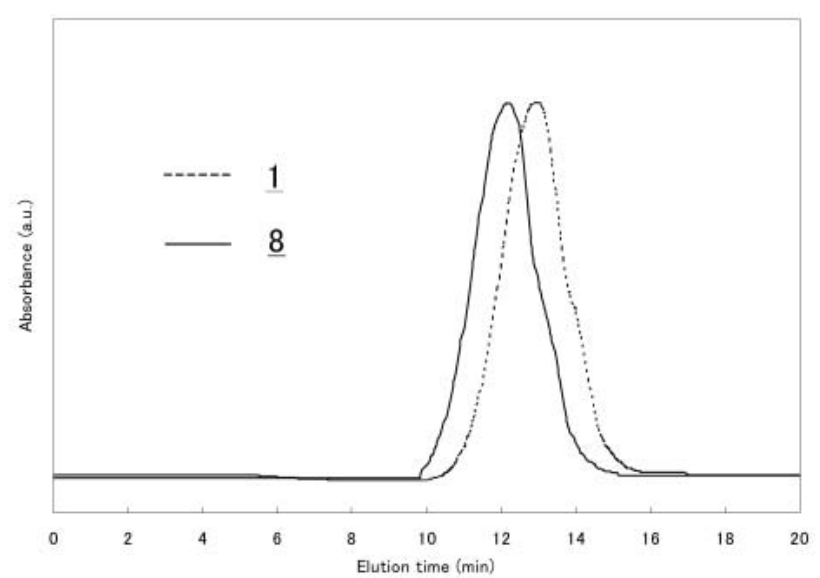

Fig. 3 GPC Elution Curves for Hemoglobin (1) and Reconstituted Hemoglobin Modified with PEG (8).

されることが知られている。そこで本研究では Activated-PEG を用いることにより，分子量 100000 以上の PEG 修飾へモグロビンを得ることを目指した。Table 1 に示したように，へモグロビンは 1 分子当り 7.9 本〜 9.0 本 (平均 8.24 本) の PEG によって修飾され, 分子 量 100000 を超える PEG 修飾再構成へモグロビンが得 られた。なお、修飾された PEGの本数は、以下の（2） 式を用いて算出した。

$$
\frac{M_{\mathrm{n}}-64500(\mathrm{Hb})-229.1(\mathrm{PLP})}{7894.3(\text { Activated-PEG })}
$$

=修飾された PEGの本数

\section{$3 \cdot 2$ SOD 活性評価}

$3 \cdot 2 \cdot 1 \quad$ シトクローム $c$ 法

各種 PEG 修飾再構成へモグロビン $(6$ ～9）の SOD 活性を, シトクローム $c$ 法 $(14,25,26)$ により測定し た。一般に，(3) 式によって生成した $\mathrm{O}_{2}^{-} \cdot$ は, フェリ シトクローム $c\left[\right.$ Cyt. $\left.c\left(\mathrm{Fe}^{3+}\right)\right]$ をフェロシトクローム $c$ [Cyt. $c\left(\mathrm{Fe}^{2+}\right) \lambda_{\max } 550 \mathrm{~nm}$ ]へ還元 [(4) 式]するが， SOD 活性を有する物質の介在により（1）式が促進さ れ，この還元反応が阻害される。この阻害の度合いを 分光学的手法 [Cyt. $c\left(\mathrm{Fe}^{2+}\right)$ に由来する $550 \mathrm{~nm}$ での吸 光度測定］により求めることができる。

$$
\begin{gathered}
\text { Xanthine }+2 \mathrm{O}_{2}+\mathrm{H}_{2} \mathrm{O} \longrightarrow \\
\text { Uric acid }+2 \mathrm{O}_{2}^{-} \cdot+2 \mathrm{H}^{+}
\end{gathered}
$$

Cyt. $c\left(\mathrm{Fe}^{3+}\right)+\mathrm{O}_{2}^{-} \cdot \longrightarrow$ Cyt. $C\left(\mathrm{Fe}^{2+}\right)+\mathrm{O}_{2}$

[XOD : xanthine oxidase, Cyt. $c\left(\mathrm{Fe}^{3+}\right)$ : ferri- cytochrome $c$, Cyt. $c\left(\mathrm{Fe}^{2+}\right)$ : ferro-cytochrome $\left.c\right]$

各種再構成へモグロビンの金属ポルフィリン濃度と阻 害率（式（5））の関係を Fig. 4 に示した。罒より阻害 率 $50 \%$ における金属ポルフィリン濃度（ $\mathrm{IC}_{50}$ ) を求め, この $\mathrm{IC}_{50}$ を $\mathrm{SOD}$ 活性の指標とし, 各種 PEG 修飾再構 成へモグロビンの $\mathrm{IC}_{50}$ を Table 2 にまとめた。また, 参照物質として, ヘモグロビン $(\mathbf{1})$, 各種再構成へモ グロビン $(\mathbf{2} \sim \mathbf{5})$ 打よび低分子 SOD モデル化合物で あるカチオン性金属ポルフィリン（FeT2MePyP, FeT4MePyP, MnT2MePyP および MnT4MePyP) につ いても併せて示した。PEG 修飾再構成へモグロビンの $\mathrm{IC}_{50}$ 值は MnT2MePyP-Hb-PEG（8）< MnT4MePyPHb-PEG (9) < FeT2MePyP-Hb-PEG $(6)<$ FeT4MePyP-Hb-PEG（7）の順となり, 中心金属とカチ オン基の距離よりも中心金属の違いが SOD 活性に影響 を与える結果となった。これは $\mathrm{Mn}$ 錯体と $\mathrm{Fe}$ 錯体の $\mathrm{O}_{2}{ }^{-}$·との反応機構が異なることに由来すると考えられ る。内圈機構で反応すると考えられている $\mathrm{Fe}$ 錯体は， $\mathrm{Mn}$ 錯体に比べてグロビン鎖の立体障害の影響でより $\mathrm{O}_{2}{ }^{-}$.が配位しにくくなることが報告されており（31）， 本研究に扔いても同様にSOD 活性が低下したことが示 された。また，再構成へモグロビン（2）～（5）と比 較して PEG を修飾することによって SOD 活性はやや 低下した。しかしながら, 活性低下は若干であり, 安 定性を考慮すれば PGE 修飾再構成へモグロビンは優れ た SOD モデル化合物であると言える。

Inhibition efficiency $=1-\left(\mathrm{v}_{\mathrm{i}} / \mathrm{v}_{0}\right)$

$\left[\mathrm{v}_{0}\right.$ and $\mathrm{v}_{\mathrm{i}}$ are formation rates of ferro-cytchrome $c$ in the absence and the presence of the compounds having

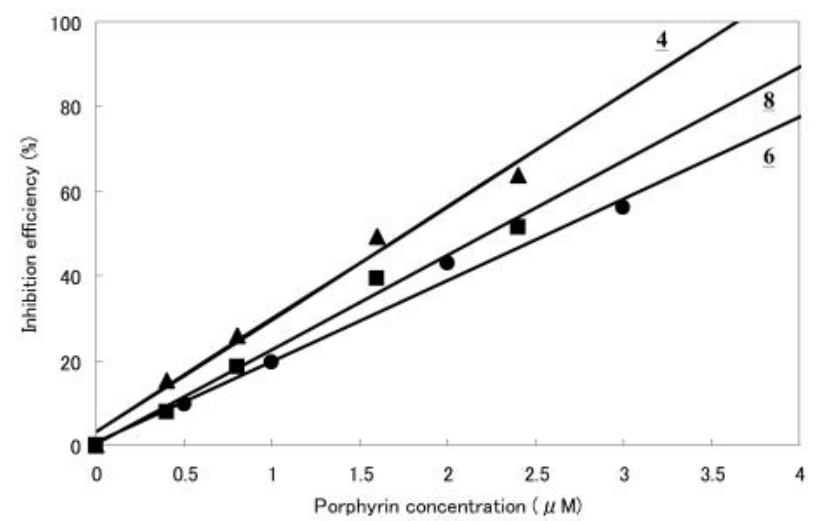

Fig. 4 Relationship between Inhibition Efficiency (\%) and Metalloporphyrin Concentration $(\mu \mathrm{M})$ of Reconstituted Hemoglobins 4 (A) (Ref. 14), 6 (O) and 8 (ם). 
Table $2 \mathrm{IC}_{50}$ Values of Various Reconstituted Hemoglobins.

\begin{tabular}{ccc}
\hline Compounds & $\mathrm{IC}_{50}(\mathrm{Mm})$ & Ref. \\
\hline $\mathbf{2}$ & 5.1 & 14 \\
$\mathbf{3}$ & 3.2 & This work \\
$\mathbf{4}$ & 1.8 & 14 \\
$\mathbf{5}$ & 2.0 & " \\
$\mathbf{6}$ & 2.7 & This work \\
$\mathbf{7}$ & 4.2 & " \\
$\mathbf{8}$ & 2.3 & " \\
$\mathbf{9}$ & 2.6 & 14 \\
$\mathbf{1}$ & 25 & This work \\
FeT2MePyP & 0.60 & 32 \\
FeT4MePyP & 0.90 & 5 \\
MnT2MePyP & 0.23 & " \\
MnT4MePyP & 0.71 & \\
\hline
\end{tabular}

SOD activity, respectively.]

\section{$3 \cdot 2 \cdot 2$ ストップトフロー法}

PEG 修飾再構成へモグロビン（8）の SOD 活性をス トップトフロー法（27）により測定した。SOD モデル の水溶液と $\mathrm{KO}_{2}$ の DMSO 飽和溶液を混合し, $\mathrm{KO}_{2}$ によ り発生した $\mathrm{O}_{2}{ }^{-} \cdot$ ・の $\lambda_{\text {max }}$ (270 nm 付近) における吸光度 の経時変化から反応速度を求めた。SOD モデルと $\mathrm{O}_{2}{ }^{-}$. の反応は, 金属の還元反応が律速であるので, 自己不 均化の速度定数を $k_{\mathrm{self}}$, SOD モデルによる $\mathrm{O}_{2}{ }^{-}$.の消失 の二次反応速度定数を $k_{\mathrm{cat}}$ とすると（6）式が成り立つ。 SOD 活性は, $\mathrm{O}_{2}{ }^{-} \cdot$ の消失が自己不均化よりも速くなっ たときに有効となるので， $k_{\text {cat }}$ が $k_{\text {self }}$ より十分大きいも のとすると, (6) 式の kself $\left[\mathrm{O}_{2}{ }^{-} \cdot\right]^{2}$ の項は無視でき る。従って $\mathrm{O}_{2}{ }^{-}$・の消失速度は（7）式のようになる。

$$
\begin{aligned}
& -\mathrm{d}\left[\mathrm{O}_{2}{ }^{-} \cdot\right] / \mathrm{d} t \\
& =k_{\text {self }}\left[\mathrm{O}_{2}{ }^{-} \cdot\right]^{2}+k_{\text {cat }}\left[\mathrm{O}_{2}{ }^{-} \cdot\right][\text { SOD model }] \\
& -\mathrm{d}\left[\mathrm{O}_{2}{ }^{-} \cdot\right] / \mathrm{d} t=k_{\text {cat }}\left[\mathrm{O}_{2}{ }^{-} \cdot\right][\text { SOD model }]
\end{aligned}
$$

また，触媒であるSOD モデルの濃度は一定と考え， $\mathrm{O}_{2}{ }^{-}$.の消失速度は見かけの反応速度定数 $k_{\mathrm{obs}}$ を用いて 表すと，（8）式のようになる。

$$
\begin{gathered}
-\mathrm{d}\left[\mathrm{O}_{2}{ }^{-} \cdot\right] / \mathrm{d} t \\
=k_{\mathrm{cat}}\left[\mathrm{O}_{2}{ }^{-\cdot} \cdot\right][\text { SOD model }] \\
=k_{\mathrm{obs}}\left[\mathrm{O}_{2}^{-} \cdot\right] \\
\left(k_{\mathrm{obs}}=k_{\mathrm{cat}}[\mathrm{SOD} \text { model }]\right)
\end{gathered}
$$

（8）式を $t$ について解くと（9）式が得られ（ln $\left[\mathrm{O}_{2}{ }^{-} \cdot\right]_{t=0}$ は積分定数），(9) 式がストップドフロー法 に打ける $\mathrm{O}_{2}{ }^{-}$.の消失速度の算出式に相当する。

$$
\begin{gathered}
\Delta \ln \left[\mathrm{O}_{2}^{--} \cdot\right]=k_{\mathrm{obs}} \cdot t \\
\left(\Delta \ln \left[\mathrm{O}_{2}^{-} \cdot\right]=\ln \left[\mathrm{O}_{2}^{-} \cdot\right]_{t=0}-\ln \left[\mathrm{O}_{2}^{-} \cdot\right]_{t=t}\right) \\
\mathrm{O}_{2}{ }^{-} \cdot \text { の濃度は吸光度 (Abs) で置き換えられるので, }
\end{gathered}
$$

（10）式が得られ,

$$
\Delta \ln \mathrm{Abs}=k_{\mathrm{obs}} \cdot t=k_{\mathrm{cat}}[\mathrm{SOD} \text { model }] \cdot t
$$

この式を用いて PEG 修飾再構成へモグロビン $(8)$ の $\mathrm{O}_{2}{ }^{-}$. 濃度の経時変化を調べた (Fig. 5)。一般に高分 子は分散性が低いので, DMSO と緩衝溶液のミキシン グを行うストップトフロー法ではうまく測定できない ことがある。PEG 修飾後の分子量は 10 万を超えるが， 8 は問題なく $\mathrm{O}_{2}{ }^{-}$.の減衰曲線が得られた。これは PEG （非イオン性界面活性剂）が両親媒性であることに由来 し, PEG 修飾再構成へモグロビン（8）は分散性の面で も優れた SOD モデルとして期待できることが示唆され た。次に Fig. 5 の吸光度（縦軸）を自然対数に変換し， 得られる擬一次直線の傾きから, 8 の金属ポルフィリン 濃度 $(0,8,16 \mu \mathrm{M})$ に対する $k_{\text {obs }}$ を算出した（Fig. 6)。 さらに金属ポルフィリン濃度に対して $k_{\mathrm{obs}}$ をプロット

(Fig. 7) し, その直線の傾きから $k_{\text {cat }}$ を求め, この $k_{\text {cat }}$ を SOD 活性の指標とした。 8 , 再構成へモグロビン（2 および 4) 打よび低分子系 SOD モデル化合物であるカ チオン性金属ポルフィリン（MnT2MePyP および MnT4MePyP) の $k_{\text {cat }}$ を Table 3 に示した。 $k_{\text {cat }}$ 值は MnT2MePyP-Hb (4) > MnT2MePyP-Hb-PEG（8）> FeT2MePyP-Hb（4）の順となり，8 4 と比較すると PEG 修飾型は若干の活性低下がみられたが， Fe 系の 2 と同等の活性を示した。

\section{3 $\mathrm{H}_{2} \mathrm{O}_{2}$ に対する安定性評価}

$\mathrm{SOD}$ 活性を有する物質は, $\mathrm{O}_{2}{ }^{-}$·を不均化させること により $\mathrm{H}_{2} \mathrm{O}_{2}$ を生成する。この $\mathrm{H}_{2} \mathrm{O}_{2}$ が低分子系の $\mathrm{SOD}$ モデル化合物の劣化・分解を誘発することが報告され ている (3)。そこで, PEG 修飾再構成へモグロビン (8) の $\mathrm{H}_{2} \mathrm{O}_{2}$ に対する安定性を, 既報 (14, 28-30) を参 考にして調べた。具体的には, SOD モデル化合物に $\mathrm{H}_{2} \mathrm{O}_{2}$ 添加後, Soret 带の減衰曲線が定常状態に達する 時間を SOD モデル化合物の分解・消失時間 $\left(t_{\mathrm{d}}\right)$ とし

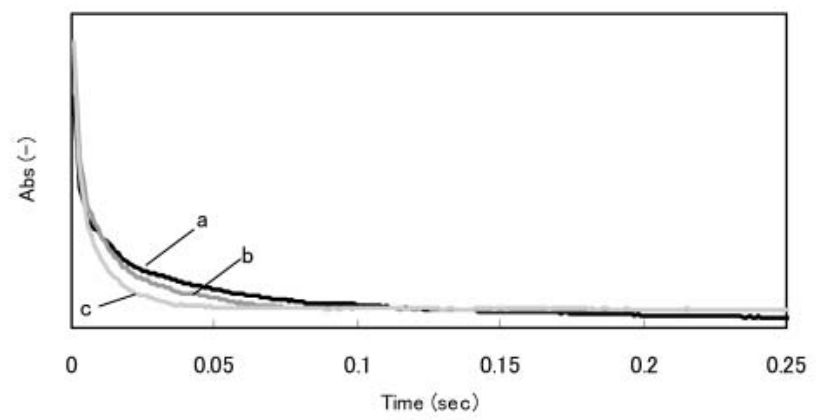

Fig. 5 Absorbance Changes at 270nm during the Reaction of $\mathbf{8}$ and $\mathrm{KO}_{2}$ in Phosphate Buffer Solution at $37^{\circ} \mathrm{C}$. MnT2MPyP conc. $(\mu \mathrm{M})$ of $\mathbf{8}: \mathrm{a}, 0 ; \mathrm{b}, 8 ; \mathrm{c}, 16$. 


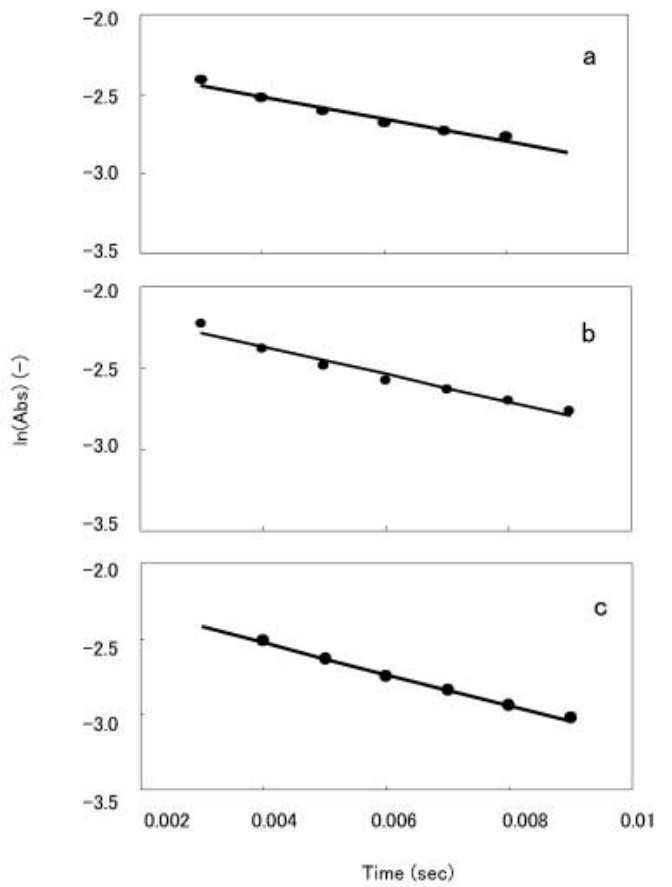

Fig. 6 Relationship between $\ln (\mathrm{Abs})$ at $270 \mathrm{~nm}$ and Time for the Reaction of $\mathbf{8}$ with $\mathrm{KO}_{2}$. MnT2MPyP conc. $(\mu \mathrm{M})$ of $\mathbf{8}$ : a, $0 ; \mathrm{b}, 8$; c, 16.

て求めた。 8 , へモグロビン (1), 再構成へモグロビン （4）打よび低分子のカチオン性金属ポルフィリン (MnT2MePyP) の $t_{\mathrm{d}}$ を Fig. 8 に示す。 8 の $t_{\mathrm{d}}$ は MnT2MePyPに比較して著しく増加した。これは，再 構成されたポルフィリンは周辺がグロビン鎖に取り囲 まれているため, $\mathrm{H}_{2} \mathrm{O}_{2}$ による直接的な開環反応が抑制 されたと考えられる。また, 8 の $\mathrm{H}_{2} \mathrm{O}_{2}$ に対する安定性 は 4 に比べ 2 倍であった。従って, $\mathrm{H}_{2} \mathrm{O}_{2}$ に対する $\mathrm{PEG}$ 修飾は, 安定性を効果的に向上させることが明らかと なった。

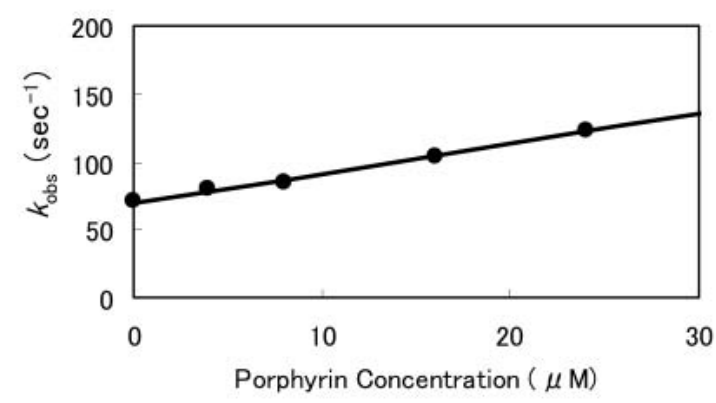

Fig. 7 Relationship between $k_{\text {obs }}$ and Metalloporphyrin Concentrations $(\mu \mathrm{M})$ in $\mathbf{8}$.
Table $3 k_{\text {cat }}$ Values of Various Reconstituted Hemoglobins.

\begin{tabular}{ccc}
\hline Compound & $k_{\text {cat }}\left(\times 10^{6} \mathrm{M}^{-1} \mathrm{~s}^{-1}\right)$ & Ref. \\
\hline $\mathbf{2}$ & 2.1 & This work \\
$\mathbf{4}$ & 3.6 & $"$ \\
$\mathbf{8}$ & 2.2 & " \\
MnT2MePyP & 60 & 33 \\
MnT4MePyP & 14 & This work \\
\hline
\end{tabular}

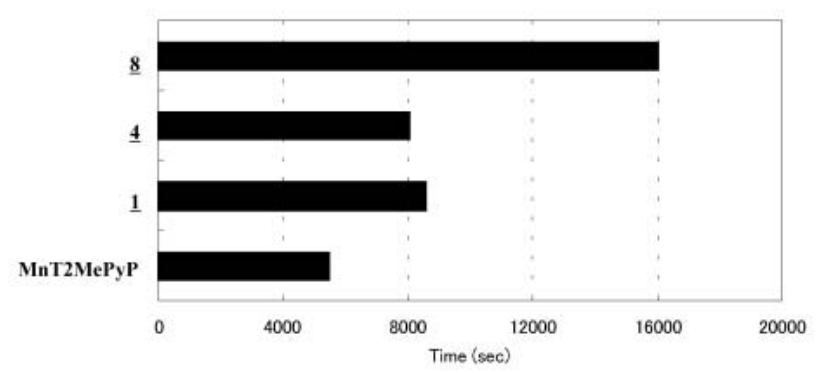

Fig. 8 Disapperance times $\left(t_{\mathrm{d}}\right)$ of Reconstituted Hemoglobins Modified with PEG (8), Hemoglobin (1), Reconstituted Hemoglobins (4), and MnT2MPyP under Conditions of $\mathrm{H}_{2} \mathrm{O}_{2}$ : Por (molar ratio) $=1000$ : 1. (See Ref. 14 for data obtained under conditions of $\mathrm{H}_{2} \mathrm{O}_{2}$ : Por (molar ratio) $=300: 1$ for 4 and 1.)

\section{$3 \cdot 4$ アルブミンとの凝集性評価}

血漿には，アルブミンが約 50 〜 60\%含まれており， 浸透圧維持と栄養物質や薬物輸送の仲介を担っている。 PEG で修飾されたへモグロビンは, 非自己タンパクと して認識されないので, 白血球により代謝されること はなく，極めて安定に存在することが知られている。 そこで，血漿の主成分であるアルブミンと PEG 修飾再 構成へモグロビン（8）との凝集能を, UV-vis. スペク トルにより測定した。具体的には，SOD モデル化合物 にヒト血清アルブミンを添加後, Soret 帯の吸光度が増 加した時間を, SOD モデル化合物の凝集時間 $\left(t_{\mathrm{a}}\right)$ と して求めた。 $8, \mathbf{1}, \mathrm{MnT} 2 \mathrm{MePyP}$ およびモデル化合物を 添加しない場合 $t_{\mathrm{a}}$ を Fig. 9 に示す。 8,1 および MnT2MePyPは，いずれもモデル化合物を添加しない 場合より若干 $t_{\mathrm{a}}$ が減少したが，低分子モデル化合物 (MnT2MePyP) と高分子モデル化合物（8, 1) は，ほ ぼ同程度の安定性を有することが明らかとなった。

\section{4 結 論}

$\mathrm{O}_{2}{ }^{-}$·を不均化して代謝を促進する SOD モデル化合物 を設計するに当たり，アポへモグロビンをキャリアー 


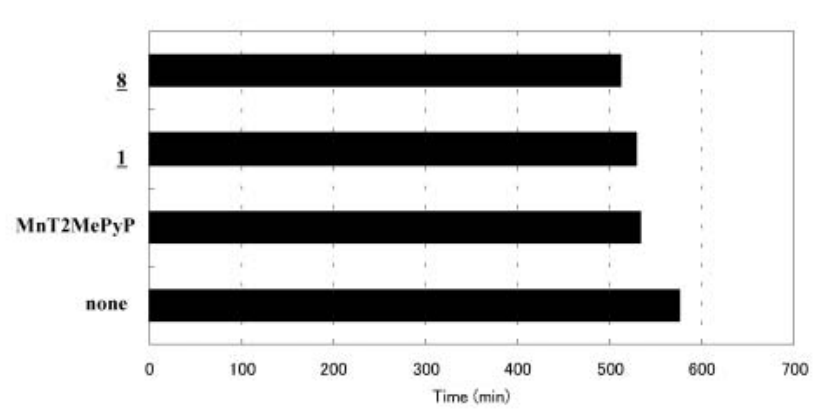

Fig. 9 Apperance Times $\left(t_{\mathrm{a}}\right)$ of Reconstituted Hemoglobin Modified with PEG (8), Hemoglobin (1) and MnT2MPyP.

とし, 活性部位として金属ポルフィリン錯体を導入し た再構成へモグロビンを合成し，さらなる安定性向上 を図るため PEG 修飾再構成へモグロビンを合成した。 その結果，次の結論が得られた。

(1) PEG 修飾再構成へモグロビン $(6$ ～9） は良好 な SOD 活性を示し, 中でも 8 は顕著な SOD 活性を示 した。その指標である $\mathrm{IC}_{50}, k_{\mathrm{cat}}$ はそれぞれ $2.3,2.2 \times$ $10^{6}$ であった。

（2）8の $t_{\mathrm{d}}$ は，低分子モデル化合物（MnT2MePyP） のそれと比較すると数倍向上し, 効果的な $\mathrm{H}_{2} \mathrm{O}_{2}$ 耐性を 有することが明らかになった。

(3) 8 の $t_{\mathrm{a}}$ は MnT2MePyP と比較して同等であり， アルブミンとの凝集能はほとんど促進されなかった。

（4）本研究によって, カチオン性マンガンポルフィ リンを含む PEG 修飾再構成へモグロビン（8）は， $\mathrm{H}_{2} \mathrm{O}_{2}$ 耐性を有し，また，アルブミンとの凝集性の低い 有効な長期血中滞留型 SOD モデル化合物であることが 明らかになった。

\section{References}

1. M. YUASA, Biomimetic Technologies of Heme Protein Systems, Oleoscience, Vol. 1, 131-137 (2001).

2. H. KAWAKAMI, Control of Reactive Oxygen Species by Water-soluble Cationic Metalloporphyrin, Oleoscience, Vol. 1, 157-165 (2001).

3. R.F. PASTERNACK and B. HALLIWELL, Superocide Dismutase Activeties of An Iron Porphyrin and Other Iron Complexes, J. Am. Chem. Soc., Vol. 101, 1026-1031 (1979).

4. D. SOLOMON, P. PERETZM and M. FARAGGI, Chemical Properties of Water-soluble Porphyrins. 2. The Reaction of Iron(III) tetrakis(4- $N$-methylpridyl) porphyrin with the Superoxide Radical Dioxygen Couple, J. Biol. Chem., Vol. 86, 18421849 (1982).

5. K.M. FAULKMER, S.I. LIOCHEV and I. FRIDOVICH, Stable
Mn(III) Porphyrins Mimic Superoxide Dismutase in vitro and Substitute for it in vivo, J. Biol. Chem., Vol. 269, 23471-23476 (1994).

6. D.P. RILEY and R.H. WEISS, Manganese Macrocyclic Ligand Complexes as Mimics of Superoxide Dismutase, J. Am. Chem. Soc., Vol. 116, 387-388 (1994).

7. K. WADA, Y. KOBAYASHI and A. YOKOYAMA, Copper(II) [2, 3butanedione-bi (4- $N$-methyltiosemicarbazone)], a Stable Superoxide Dismutase-like Copper Complex with High Membrane Penetrability, Arch. Biophys. Biochem., Vol. 310, 1-5 (1994).

8. Z.X. LIU, G.B. ROBINSON and E.M. GREGORY, Preparation and Characterization of Mn-salophen Comlex with Superoxide Scavenging Activity, Arch. Biophys. Biochem., Vol. 315, 74-81 (1994).

9. J.L. PIERRE, P. CHAUTEMPS, S. REFAF, C. BEGUIN, A.E. MARZOUKI, G. SERRATRIE, E. SAINT-AMAN and P. RAY, Imidazolate-bridged Dicopper(II) and Copper-zinc Complexesof a Macrocyclic Ligand (Cryptand). A Possible Model for the Chemistry of Cu-Zn Superoxide Disumutase, J. Am. Chem. Soc., Vol. 117, 1965-1973 (1995).

10. H. KAWAKAMI, T. OHSE and S. NAGAOKA, SOD Activity Water-soluble Metalloporphyrins, Porphyeins, Vol. 4, 23-27 (1995).

11. A. DEROCHE, I. MORGENSTERN-BADARAU, M. CESARRIO, J. GUIKHEM, B. KEITA, L. NADJO and C. HOUEEKLEVIN, A Seven Coorinate Manganese(II) Complex formed with a Single Tripodal Heptadentate Ligand as a New Superoxide Scavenger, J. Am. Chem. Soc., Vol. 118, 4567-4573 (1996).

12. H. KAWAKAMI, T. NAKAJMA, T. MORI, S. ASAYAMA, S. NAGAOKA, T. OHIRA, U. MIDORIKAWA and M. YUASA, SOD Activity of Cationic-porphrin Having a Cationic Channel, Inter. Symp. Biomater. DDS, Proc., p.176 (2000).

13. A. YAMAGUCHI, T. ISHINO, N. MATSUKURA, H. KAWAKAMI, S. ASAYAMA, S. NAGAOKA and M. YUASA, Superoxide Dismutase Activities of Iron- porphyrins Modified with Poly(L-lysine), J. Oleo Sci., Vol. 52, 269-276 (2003).

14. M. YUASA, A. YAMAGUCHI, S. MIKAMI, U. MIDORIKAWA, H. KAWAKAMI, S. NAGAOKA, Syntesis of Reconstistuted Hemoglobins Containg Metallo- porphyrin Derivatives and SOD Activity, J. Oleo Sci., Vol. 52, 149-157 (2003).

15. K. KALYANASUNDARAM, Photochemisty of Water-soluble Porphyrins : Comparative Study of Isomeric Tetrapyridyl- and Tetrakis(N-methypyridiniumyl) Porphyrins, Inorg. Chem., Vol. 23, 2353-2459 (1984).

16. R.F. PASTENECK, L. FRANCESCONI, D. RAFF and E. SPIRO, Aggregation of Niclel(II), Copper(II), and Zinc(II) Derivatives of Water-soluble Porphrins, Inorg. Chem., Vol. 12, 2606-2611 (1973).

17. P. HAMBRIGHT, T. GORE and M. BURTON, Synthesis and Characterization of New Isomeric Water-solulbe Porphyrins. Tetra(2-N-methylpryidyl)porphine and Tetra(3-N-methylpyridyl)-porphine, Inorg. Chem., Vol. 15, 2314-2315 (1976).

18. A.D. ADLER, F.R. LOMGO, F. KAMOAS and J. KIM, On the 
Preparaion of Metalloporphyrins, Nucl. Chem., Vol. 32, 24432445 (1970).

19. T. YONETANI, H.R. DROTT, J.S. LEIGH, G. REED, M.R. WATERMAN and T. ASAKURA, Electromagnetic Properties of Hemoproteins. 3. Electron Paramagnetic Resonance Characteristics of Iron(II) and Manganese(II) ProtoporphyrinIX and their Apohemoprotein Complexes in High Spin States, J. Biol. Chem., Vol. 245, 2988-3003 (1970).

20. F. ASCOLI, M. ROSARIA, R. FANELLI and E. ANTONINI, Preparation and Properties of Apohemoglobin and Reconstituted Hemoglobins, Methods in Enzymology, Vol. 76, $72-87$ (1981).

21. M.R. WATERMAN and T. YONETANI, Studies on Modified Hemoglobins. I. Properties of Hybrid Hemoglobins Containing Manganese ProtoporphyrinIX, J. Biol. Chem., Vol. 245, 21, 5847-5852 (1970).

22. P.E. KEIPERT and T.M. CHANG, Preparation and in vitro Characteristics of a Blood Substitute Based on Pridoxylated Polyhemoglobin, Applied Biochem. Biotec., Vol. 10, 133-141 (1984).

23. K. IWASAKI and K. AJISAKA and Y. IWASHITA, Hemoglobin-inulin Conjugate as an Oxygen Carrying Blood Substitutes, Biochem. Biophys. Res. Commun., Vol. 113, 513-518 (1986).

24. Y. IWASHITA, Prydoxalated Hemoglobin-Polyoxyethylene Conjugate (PHP) as an Oxygen Carrier, Artificial Organs Today, Vol. 1, 89-114 (1991).

25. J.M. MCCORD and I. FRIDOVICH, Superoxide Dismutase. An Enzymic Function for Erythrocuprein (Hemocuprein), J. Biol. Chem., Vol. 244, 6049-6055 (1969).

26. J. BUTLER, W.H. KOPENOL and E. MARGOLIASH, Kinetics and Mechanism of the Reduction of Ferricytochrome $c$ by the Superoxide Anion, J. Biol, Chem., Vol. 257, 10747-10750
(1982).

27. D.P. RILEY, W.J. RIVERS and R.H. WEISS, Stopped-flow Kinetic Analysis for Monitoring Superoxide Decay in Aqueous Systems, Anal. Biochem., Vol. 196, 344-349 (1991).

28. R.K. ROOT and J.A. METCALF, $\mathrm{H}_{2} \mathrm{O}_{2}$ Release from Human Gramulocytes during Phagocytosis. Relationship to Superoxide Anion Formation and Cellular Catabolism of $\mathrm{H}_{2} \mathrm{O}_{2}$ : Studies with Normal and Cytchalasin B-treated Cells, J. Clinc. Invest., Vol. 60, 1266-1279 (1977).

29. L.A. RIO, M.G. ORTEGA and A.L. LOPEZ, A More Sensitive Modification of the Catalase Assay with the Clark Oxygen Electrode. Application to the Kinetic Stydy of the Pea Let Enzyme, Anal. Biochem., Vol. 80, 409-415 (1977).

30. E.E. DI IORIO, Preparatiob Derivatives of Ferrous and Ferric Hemoglobin, in Methods in Enzymology, Vol. 99, 57-72 (1981).

31. D. ZHANG, H. BUSCH, P.L. LENNON, R.H. WEISS, W.L. NEUMANN and D.P. RILEY, Iron(III) Complexes as Superoxide Dismutase Mimics: Synthesis, Characterization, Crystal Structure, and Superoxide Dismutase (SOD) Activity of Iron(III) Complexes Containing Pentaaza Macrocyclic Ligand, Inorg. Chem., Vol. 37, 956-963 (1998).

32. R.H. WEISS, A.G. FLICLINGER, W.J. RIVERS, M.M. HARDY, K.W. ASTON, U. RYAN and D.P. RILEY, Evaluation of Activity of Putative Superoxide Dismutase Mimics. Direct Analysis by Stopped-flow Kinitics, J. Biol. Chem., Vol. 268, 23049-23054 (1993)

33. R. KACHADOURIAN, I.B. HABERLE, I. FRIDOVICH, Synteses and Superoxide Dismuting Activities of Partially (1-4) $\beta$ Chlorinated Derivatives of Manganese(III) meso-Tetrakis(Nethylpridinium-2-yl)porphyrin, Inorg. Chem., Vol. 38, 391-396 (1999). 